\title{
Pekanbaru City Snack E-Commerce Application Design Based on Android
}

\author{
Panji Rachmat Setiawan', Ardiansyah ${ }^{2}$ \\ Departement of Informatic Engineering, Engineering Faculty, Universitas Islam Riau ${ }^{1,2}$ \\ panji.r.setiawan@eng.uir.ac.id ${ }^{1}$, ardiyansyah69@student.uir.ac.id ${ }^{2}$
}

\begin{tabular}{l}
\hline \hline Article Info \\
\hline Article history: \\
Received Okt 27, 2021 \\
Revised Dec 21, 2021 \\
Accepted Jan 3, 2022
\end{tabular}

\section{Keyword:}

E-Commerce

Android

Waterfall

City Snack

Application

\begin{abstract}
E-Commerce is a concept that quite developed in the field of information technology. E-Commerce gives more convenience and advantages when compared with conventional, including all the information needed by cunsomers can be accessed more detail, without being limited with place and time, and transactions process can be done much easier. So that the implementation of this system will make it easier and more profitable for many parties, both consumers and sellers. This development method in building ECommerce application is based on the theory of the Waterfall Model. Waterfall is a software development methodology, which proposes an approach to systematic and sequential software which starts at the system progress level throughout the analysis, design, code, testing and maintenance. The purpose of this research is to produce Pekanbaru city snack E-Commerce application based on android. By implementing this system will make it easier and more profitable for many parties, both consumers and sellers.
\end{abstract}

(C) This work is licensed under a Creative Commons AttributionShareAlike 4.0 International License.

\section{Corresponding Author:}

Panji Rachmat Setiawan, S.Kom., MMSI

Departement of Informatic Engineering,Engineering Faculty

Universitas Islam Riau

Jl. Kaharuddin Nst No. 113, Simpang Tiga, Kec.Bukit Raya, Pekanbaru, Riau, Indonesia

Email: panji.r.setiawan@eng.uir.ac.id

\section{INTRODUCTION}

Nowadays, technology development is very advanced. Almost all of people connected using internet. By using this technology, it can help people become more effective and efficient. Because today human become more productive, and then likes everything practical.

The business of buying and selling food is becoming a trend in all circles. It can be seen from many social media accounts selling foods by online or offline. As an example, so many social media account that selling foods, dessert, and drinks, using Instagram as a pioneer to promote their goods [1]. The location of the food seller, which is sometimes far from the buyer's location, makes it difficult for buyers to buy the food. And sometimes, buyers don't know where the exact location of food sellers is.

Snacks in Pekanbaru are convently growing rapidly and can be found everywhere. Associated with technological developments and human needs, the idea come to create a snack application that aims to make it easier for consumers and sellers [2]. Kenneth J. Laudon, Jane P. Laudon defined e-commerce as, "The process of buying and selling goods electronically by 
consumers and from company to company through computerized business transaction" [3]. ECommerce technology is a business mechanism which works electronically by focusing only online business transactions and has the opportunity to build more human and personalized relationship with customers [4].

From the background of these problems, through this research, author will develop an online snack application. The purpose from this research is to produce Pekanbaru City Snack ECommerce Application Based on Android.

\section{RESEARCH METHOD}

In this research, author using literature study, interview, and observation for collecting data, analyze current system, and design a system using diagram to build an application using android technology.

Explaining research chronological, including research design, research procedure (in the form of algorithms, Pseudocode or other), how to test and data acquisition [1]-[3]. The description of the course of research should be supported references, so the explanation can be accepted scientifically [2], [4].

\subsection{Literature Study}

By doing research in the library, looking for books, journals, and articles relate for this research. First journal is about creating an e-commerce app based on android for market snack. This research focused on how people troubled to find snacks in the market, because they sold in conventional way, or we must attend the market to buy snacks. The problem is, not every people know when seller start and stop selling snacks, what day, and where are they in the market. Using Customer Relationship Management (CRM) method, this research produces an e-commerce app for people who wants to buy snack and place an order online [5]. Shortcomings of this study, we don't know when seller send snack, and there will be possibility that snack ordered is stale, because not all snacks can last long.

Next journal is research focused on how an e-commerce app based on android can helping self-help groups in the village of Margakaya Pringsewu, with the aim of monitoring the marketing of small and medium business product. This research using System Development Life-Cycle method for development [6].

The third one is about how an android application can help ordering some food. This research focuses on customer satisfaction. The more customer happy, more snacks they buy. Question is how we can make customer happy. To make customer happy, we must focus on service. Good service not only about the price, there's also so many aspects if we want to give good service. Information about food, availability, portion size, even calories contain in food. This can help people who on diet, or have any disease [7].

Next research article is about how to design and implementation e-commerce for online cloth store sales based on android [8]. Based on whitebox method testing, customer satisfaction buy cloth using e-commerce application increase $70 \%$.

This research also discusses how snack ordered can be sent to the customer who buy it, and ensure the snack ordered safely reaches its destination. Next article is about how to monitor the courier on the petshop. This research using websocket to provide real-time location information so that it can display location points [9].

\subsection{Interview}

Esterberg says about interview is, "a meeting of two persons to exchange information and idea through question and responses, resulting in communication and joint construction of meaning about a particular topic" [10]. Author also doing an interview with sellers to get data for development and creating good quality service for customers. First question author always ask to seller is how good customers knowing this snack. This question is not about how it taste, but also price, location, even when customer can buy this snack. At first, sellers always answer customers knowing well about their goods, they can tell how and when to operate, or when they must close. But at some point, there is inconsistent from sellers, like place to selling their snack, how to give 
good portion, ingredients for snack, even price for snack. Because of this inconsistent, customer can't know their goods anymore, so author can draw conclusions, this inconsistent can lower customer satisfaction.

Next interview, author ask for how customers find snacks, which is this question is for customers. Most of them said, they find snack accidentally, in the way home, going for somewhere, and sometimes because they get bored, so they buy it randomly. But in some cases, to satisfy their desires, most of them can't find good snack. Is it due to inconsistent selling times, taste, or they cannot find at all, or when customers at some place they never been there before, and they want something to eat, but they can't find snack right for their condition? Even customers cannot describe what they want, like example they want something spicy, soup based, and right to eat in the afternoon. As Susan Stainback said, "Interviewing provide the researcher a means to gain a deeper understanding of how the participant interpret a situation or phenomenon than can be gained through observation alone" [11], author now understand how sellers feels about selling their goods, and how customer feels to find something good.

\subsection{Observation}

Susan Stainback said, "In participant observation, the researcher observes what people do, listen to what they say, and participates in their activities" [11]. Author using this opportunity to observe how sellers prepare and selling their goods, and how customers find snacks, buying it, and how customers think about snack their buy. And also, Marhsal said, "Through observation, the researcher learn about behavior and the meaning attached to those behavior" [12].

\subsection{Ongoing System Analysis}

Before this snack e-commerce application designed, current process is start from sellers or customers visiting outlet and ordered snack want to buy by looking at the prices listed on the menu. Then customers pay their selected snack to the seller, and seller making a memorandum payment for customers, based on snack they ordered. For ongoing system analysis can be seen at figure 1 .

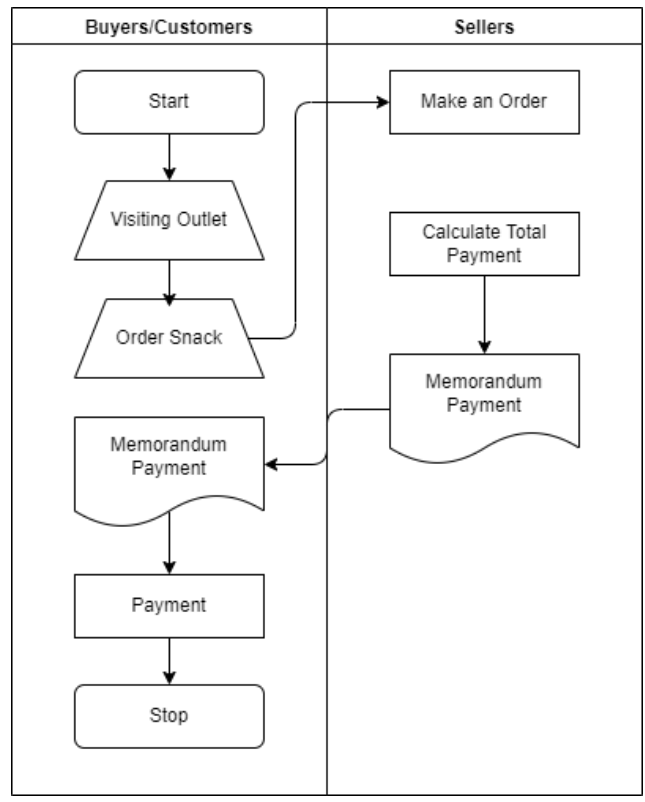

Figure 1. Ongoing System Analysis

This system runs conventionally, and this system is fragile. The question is why this system is fragile, if more customers come, and sellers can't handle properly, it can cause chaos between sellers and buyers, and top of it all, it can decrease customer satisfaction. Remember, the more customer happy, the more money can be made.

\subsection{System Development}


In this research, will be design system that can help several parties involved. Explained that a customer opens this application, and then choosing menu from outlet and snacks. After that, system will receive and calculate total order automatically. Customer will receive total order and get a courier to deliver foods. Last, seller will proceed preparing food that ordered, for next step will be send by courier which provide from application.

The difference between ongoing system and that developed is in ongoing system customers must find and locate where's seller, must know what time to visit seller, and there's time when customers can't describe and doesn't know what snack want to buy, or when customers at some place never been there, they don't know what good for them. In developed system, customers don't have to face all of it, even the application can describe what customers want based on customers profile.

While developing this system, author using data flow diagram, and entity relationship diagram design database. According to Andi Rahman, data flow diagram are used for describes the process of data flow occurs in the system from the highest level to the lowest, which makes it possible to divide the system into smaller and simpler parts [13].

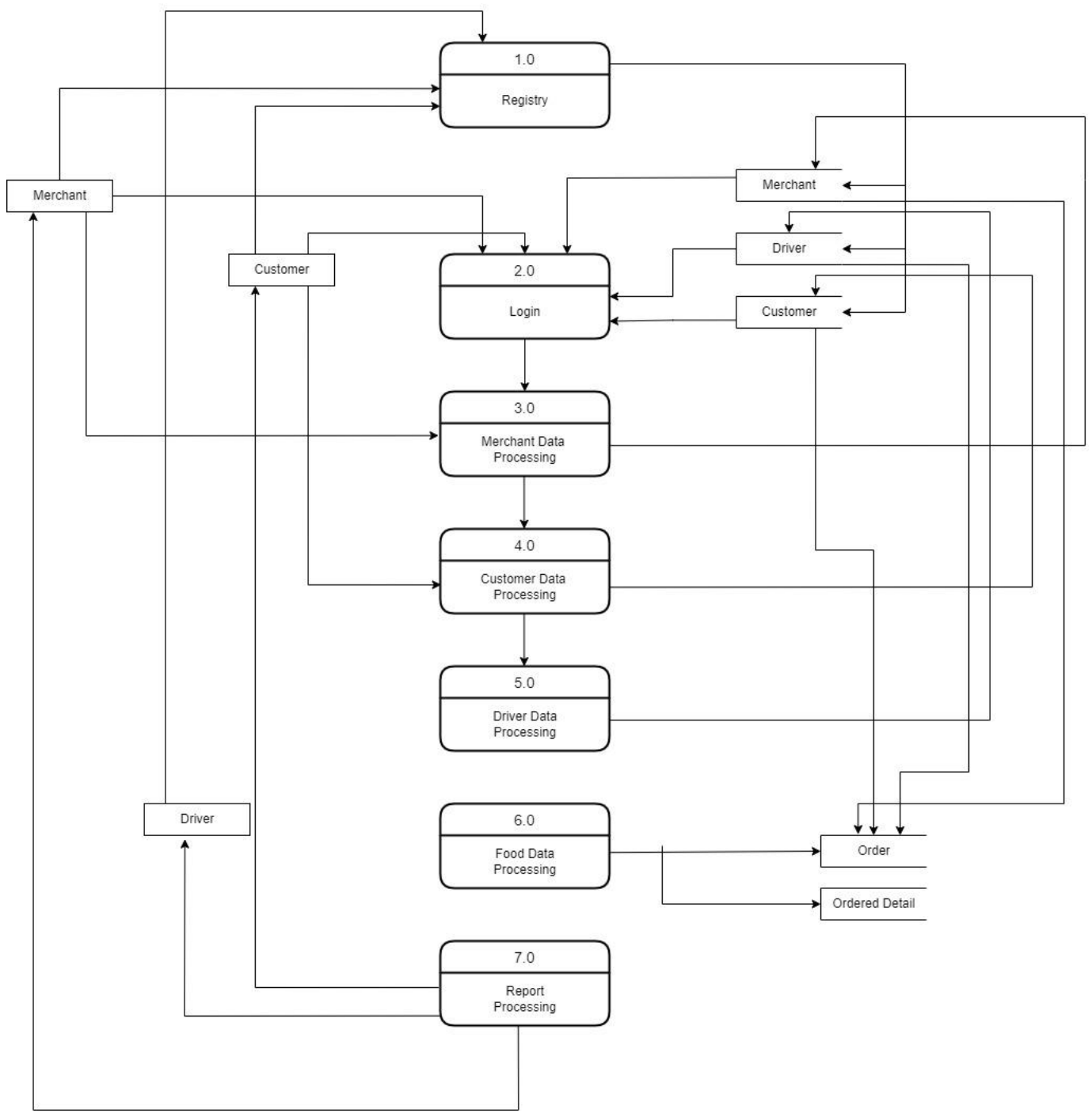

Figure 2. Data Flow Diagram

\subsection{Android}


In this research, author using android platform to running application that has been developed. Android is a Linux based operating system, designed for mobile device like smartphone and tablet pc [14]. Android is a operating system based linux for mobile device, covered operating system, middleware, and application. Smartphone that using operating system android, is more accepted in the community than smartphones that have an operating system other than android.

\subsection{MySQL}

Author using MySQL for database in this research. MySQL is a Database Management System SQL or as well known as DBMS (Database Management System) [14]. According to Raharjo, MySQL is RDBMS software, which can manage database quickly, can accommodate large amount of data, can be accessed by multi-user, and it can perform a process synchronously or concurrently(multi-threaded) [15].

\subsection{PHP}

PHP is an interpreter programming. It means the process of translating a line of source code into machine code that computer understands directly when line of code is executed [16]. PHP is called as server-side programming, this because all of process running on server, not on a client. PHP is an open source language, it means users can develop PHP function code as their needs [17].

\section{RESULTS AND ANALYSIS (11 Pt)}

\subsection{Implementation}

1. Main Page

Main page is a main menu that have three options, which are snack order menu to viewed merchant and snacks, ordered menu to view snacks that had been ordered by customers, and history menu that contains information about order that had been ordered by customers.

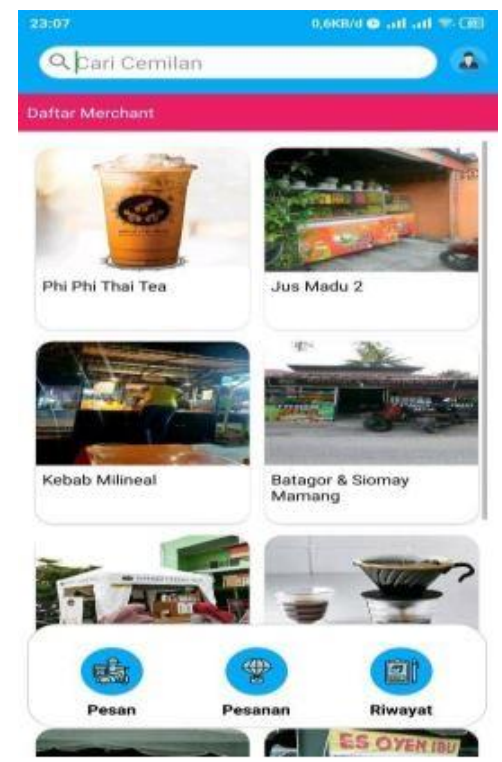

Figure 3. Application Main Menu

2. Order Menu

This page viewed all snacks that sell using this application. In this menu, customers can choose snacks that they want, and after customers choosing merchant, it shows every snack that merchant sell. 


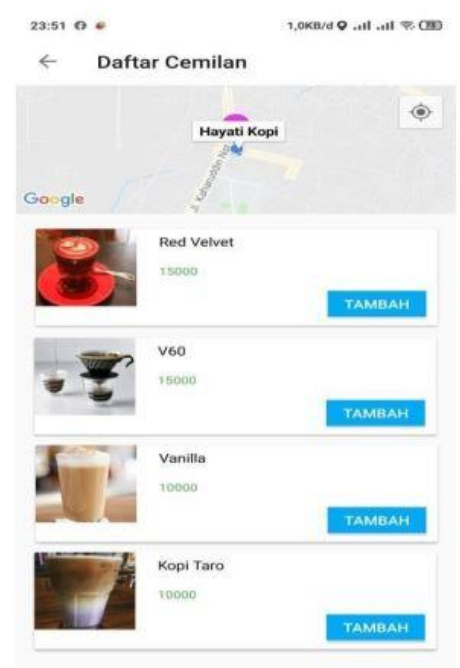

Figure 4. Snack Order Menu

3. Ordered Page

In this page, it shows every order that have been ordered by customers. If customers want to continue to the next process, they can choose checkout button.

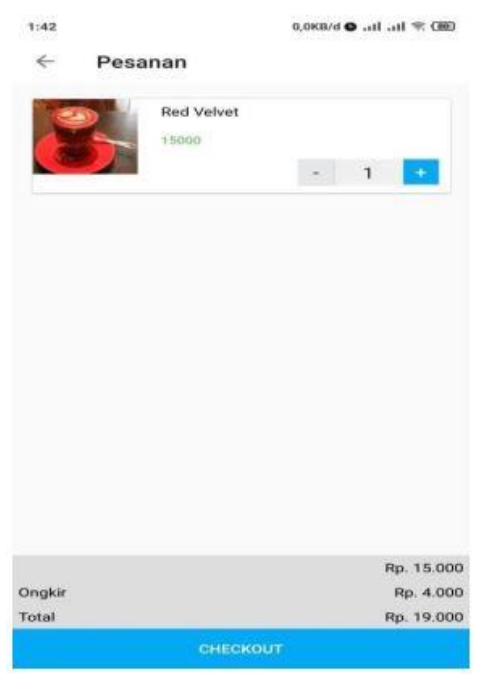

Figure 5. Ordered Page

Table 1. Application Blackbox Testing

\begin{tabular}{cccc}
\hline Item & Scenario & Expected Result & Result \\
\hline Login & $\begin{array}{c}\text { Login using correct } \\
\text { Username and } \\
\text { Password }\end{array}$ & $\begin{array}{c}\text { After inputing } \\
\text { username and } \\
\text { password, customer } \\
\text { will switch to main } \\
\text { menu }\end{array}$ & Succeed \\
& & $\begin{array}{c}\text { After inputing } \\
\text { username and } \\
\text { Login }\end{array}$ & Login using incorrect \\
& Username and & Succeed \\
& Password & $\begin{array}{c}\text { won't switch into main } \\
\text { menu, and there will } \\
\text { be an alert message }\end{array}$ & \\
\hline Profile Button & Pressing Profile & After profile button & Succeed \\
\hline
\end{tabular}




\begin{tabular}{|c|c|c|c|}
\hline & Button & $\begin{array}{l}\text { pressed, it will switch } \\
\text { to profile menu }\end{array}$ & \\
\hline Exit Button & Pressing Exit Button & $\begin{array}{l}\text { After customers } \\
\text { pressed exit button, it } \\
\text { will close the } \\
\text { application }\end{array}$ & Succeed \\
\hline Main Menu & $\begin{array}{l}\text { Pressing one of the } \\
\text { merchants to choose } \\
\text { snacks }\end{array}$ & $\begin{array}{l}\text { When customers } \\
\text { pressed one of the } \\
\text { merchants, it will view } \\
\text { snacks that prepared } \\
\text { by merchant }\end{array}$ & Succeed \\
\hline Snack List Menu & $\begin{array}{l}\text { Choosing one of the } \\
\text { snacks }\end{array}$ & $\begin{array}{l}\text { When customers want } \\
\text { to order one oof the } \\
\text { snacks, it will switch } \\
\text { to order menu }\end{array}$ & Succeed \\
\hline Details Menu & View Detail & $\begin{array}{l}\text { After entering the } \\
\text { details menu, } \\
\text { customers will be } \\
\text { shown the details of } \\
\text { the order that } \\
\text { customers have made }\end{array}$ & Succeed \\
\hline Details Menu & $\begin{array}{l}\text { Pressing Driver's } \\
\text { Location Button }\end{array}$ & $\begin{array}{l}\text { If customers want to } \\
\text { know where's driver, } \\
\text { they can press Driver's } \\
\text { Location button }\end{array}$ & Succeed \\
\hline Details Menu & Rating & $\begin{array}{l}\text { When the food has } \\
\text { been received by } \\
\text { Customers, they can } \\
\text { give rate for the food } \\
\text { and for the driver }\end{array}$ & Succeed \\
\hline
\end{tabular}

In making an android-based e-commerce snacks application for Pekanbaru City can help consumers to choose street food menu in Pekanbaru, both from traditional snack menu and contemporary snack menu.

\section{CONCLUSION}

From the results of research that has been done, author finds the conclusions, this application can help customers when they want to order snacks or food, it can help customers if they want to choose the right snack or food from profiling, or if customer is in an area, and don't know what to eat, this application can help by listing merchant in that area.

Provide a statement that what is expected, as stated in the "Introduction" chapter can ultimately result in "Results and Discussion" chapter, so there is compatibility. Moreover, it can also be added the prospect of the development of research results and application prospects of further studies into the next (based on result and discussion).

\section{REFERENCES}

[1] A. Z. Nasution, "Konsumen dan hukum: tinjauan sosial ekonomi dan hukum perlindungan konsumen Indonesia," 1995.

[2] A. M. Pertiwi and B. Lastariwati, "FAKTOR-FAKTOR YANG MEMPENGARUHI KONSUMSI DAN FREKUENSI KONSUMSI MAKANAN JAJANAN SISWA KELAS X SMKN 1 SEWON," E-Journal Student PEND. Tek. BOGA-S1, vol. 5, no. 8, 2016.

[3] K. C. Laudon and J. P. Laudon, "Management Information Systems. PRENTICE HALL." 
Inc, 1998.

[4] L. Yang and Y. Li, "Anaerobic digestion of giant reed for methane production," Bioresour. Technol., vol. 171, pp. 233-239, 2014.

[5] D. Kustiarno, "APLIKASI E-COMMERCE JAJANAN PASAR MENGGUNAKAN METODE CUSTOMER RELATIONSHIP MANAGEMENT BERBASIS ANDROID." STMIK AKAKOM Yogyakarta, 2021.

[6] R. Irviani, E. Setyorini, and M. Muslihudin, "Perancangan Aplikasi E-Commerce Berbasis Android Pada Kelompok Swadaya Masyarakat Desa Margakaya Pringsewu," J. Ilm. Ilmu Komput. Fak. Ilmu Komput. Univ. Al Asyariah Mandar, vol. 4, no. 1, pp. 8-12, 2018.

[7] P. R. Setiawan, M. Syaifullah, and P. P. Putra, "Sistem Pemesanan Menu Pada Restoran Berbasis Android," IT J. Res. Dev., vol. 5, no. 2, pp. 193-203, 2020.

[8] A. P. Kusuma and K. A. Prasetya, "Perancangan dan implementasi e-commerce untuk penjualan baju online berbasis android," ANTIVIRUS J. Ilm. Tek. Inform., vol. 11, no. 1, 2017.

[9] A. B. Kamaludin, "Aplikasi Monitoring Kurir Antar Jemput Pada Petshop Dengan Memanfaatkan Websocket Dan Flutter.” Universitas Komputer Indonesia, 2019.

[10] K. G. Esterberg, Qualitative methods in social research, no. 300.18 E8. 2002.

[11] S. Stainback and W. Stainback, Understanding \& Conducting Qualitative Research. ERIC, 1988.

[12] S. K. Marshall, A. Zaidman-Zait, J. F. Domene, and R. A. Young, "Qualitative ActionProject Method in Family Research," J. Fam. Theory Rev., vol. 4, no. 2, pp. 160-173, 2012.

[13] A. Rachman, "Sistem Pendukung Keputusan Seleksi Sumber Daya Manusia di Perusahaan," 2008.

[14] T. Willay and T. Informatika, "Berbasis Android Menggunakan Metode Priority Scheduling," pp. 1-11.

[15] B. Raharjo and B. Raharjo, "Belajar otodidak membuat database menggunakan MySQL / Budi Raharjo," 1. PANGKALAN DATA - PENGELOLAAN $<B R>2$. MYSQL (progr. KOMPUTER),Belajar otodidak membuat database menggunakan MySQL / Budi Raharjo, 2011.

[16] H. Hidayat, Hartono, and Sukiman, "Pengembangan Learning Management System (LMS) untuk Bahasa Pemrograman PHP," J. Ilm. Core IT Community Res. Inf. Technol., 2017.

[17] A. F. K. Sibero, "Kitab Suci Web Programming.” 2011.

[18] A. K. Evizal, A. Siswanto, and A. Syukur, "Performance analysis of wireless LAN 802.11n standard for e-Learning," 2016, doi: 10.1109/ICoICT.2016.7571948. 


\section{BIOGRAPHY OF AUTHORS}

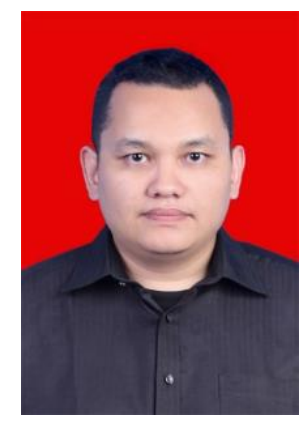

Panji Rachmat Setiawan, is a lecturer of the Department of Informatics Engineering, Universitas Islam Riau, Indonesia. Obtained his bachelor Informatics Engineering at Universitas Bina Nusantara, also known as Binus University, Jakarta, in 2009, and his master Management Information System at Universitas Bina Nusantara, Jakarta, in 2012. He is a Trainer for Java Programming (Object-Oriented Programming), and Mobile Programming.He is now involved in several projects for research in the field of mobile technology. His current research interests include mobile technology, block chain, and system designer.

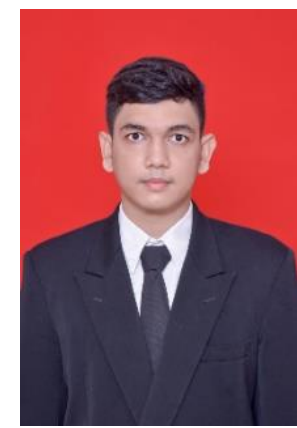

Ardiansyah, obtained Bachelor Degree in Computer Science from Universitas Islam Riau at 2021 